\title{
EFFECTS OF VerTical IRREgUlarity iN STEEL Frame With Shear Linked SteEl BRACiNgS
}

\author{
Md Mahmud SAZZAD ${ }^{1}$, Md Samdani AZAD ${ }^{2, *}$, Avishek GHOSH ${ }^{2}$ \\ ${ }^{1}$ Department of Civil Engineering, Rajshahi University of Engineering \& Technology, Bangladesh \\ ${ }^{2}$ Department of Civil Engineering, University of Creative Technology Chittagong, Bangladesh \\ *Corresponding Author: Md Samdani AZAD (email: samdani@uctc.edu.bd) \\ (Received: 29-Oct-2019; accepted: 19-Nov-2019; published: 31-Dec-2019) \\ DOI: http://dx.doi.org/10.25073/jaec.201934.265
}

\begin{abstract}
This paper deals with the irregular profile of braced steel frame building along the vertical direction with shear link bracing systems. The underlying fact of the paper is the effect of the seismic force in braced frames with different types of irregularities including geometric irregularity, column discontinuity, and overhanging mass. For each successive model, the position of shear link bracings has been fixed to make the study effective. This study has investigated the vulnerable effect of irregular profiles in steel frame buildings. To attain the nonlinear property of each element of the frame, the pushover analysis method along with the equivalent static force method has been adopted for the present study. UBC97 code has been used here for linear static analysis while the parameters for nonlinear static analysis are authenticated from FEMA356. Investigations on different frames exhibit that regular profile with symmetry in mass is more efficient while using overhanging mass is detrimental as the formation of nonlinear hinge occurs at minimum load in the model with overhanging mass compared to other frames.
\end{abstract}

\section{Keywords}

Three Steel frame, Shear link, Pushover analysis, Irregular profile.

\section{Introduction}

Steel bracings have become a common system to retrofit steel framed buildings for the last few decades. It has become accustomed because of its affectivity on increasing strength, stiffness and ductile properties of structures. Steel bracing systems are the best mean for the proper rehabilitation of existing structures which are prone to the earthquake loads since earthquake rehabilitation has become a challenge nowadays. The use of shear links has made the method more effective. With the development of the concept of using shear links with seismic bracings, researchers and structural engineers have already represented its credible performances compared to general steel bracings systems. Several studies demonstrated the development of this system for both steel and concrete structures [1-2]. Research works are still going to develop the bracing pattern with or without links. Studies with vertical shear links depict that they provide more lateral stiffness to withstand the seismic force [1]. The bracings are provided not only in regular shaped framed structures but also in irregular shaped framed structures. The studies can be carried out either experimentally or numerically. In the case of experimental studies, the shaking table test is often adopted. Shaking table test is a comprehensive test to determine the affectivity of structural frames; however, it is very costly and not widely available. 
Alternatively, numerical approaches are widely adopted.

Several researches are conducted based on experimental studies and numerical analysis. For example, Hosseini et al. [1] discussed the pushover analysis of reinforced concrete buildings with vertical shear links steel braces. The goal of their study was to strengthen the frames providing steel bracings such as inverted "V" braces, inverted "Y" shear linked braces. Several models had been selected to conduct their study. Frames of 4, 8 and 12 stories regular reinforced concrete buildings were analyzed to assess their properties and behaviors. They carried out the pushover analysis to evaluate the efficiencies of their models and it was found that the inverted Y-linked braces are good enough to resist earthquake forces as the formation of first nonlinear hinge has been found in shear links. Naik et al. [3] presented the seismic performance evaluation of reinforced concrete frames with irregular elevations using nonlinear static pushover analysis. The seismic performance of concentrically braced steel frames in multistory buildings with mass irregularity has been considered by Tremblay and Poncet [4]. Multistory frames having mass irregularity have been the focal concentration of their study. Seven incompatible frames limited to eight-story have been reviewed in this study to obtain the effect of mass irregularity. The mass irregularity along the height has been evaluated. The equivalent static force method and the response spectrum method have been adopted to compare the performance levels. Hossain et al. [5] discussed the seismic evaluation of a simple steel-framed structure by pushover analysis. A simple steel structure has been developed to assess the nonlinear behavior of a certain structural frame. Although several research works have been reported, very limited studies for steel frames with vertical irregularities considering the use of shear links have been reported. Studies of irregularities are also found in references [6-11].

The present research aims to perform a comprehensive study of the substantial effects of using shear links in different types of steel frames that have vertical irregularity. Present research deals with the study which contains some cases to exhibit a notable behavior of the steel braced frames with shear links in different irregular type frames in the vertical direction. The application of shear link and its feasibility are already studied [1]. Hence, this study considers the application of shear links in braced frames. Vertical irregularities are considered because the structures are sometimes projected beyond the mainframe to meet up the architectural requirement. Sometimes geometric irregularity and column discontinuity along the vertical direction of structures are also observed. To investigate the nonlinear behavior of irregular structures, pushover analysis is carried out. The assessment of seismic force capacity has been determined for distinct cases. Furthermore, the consequences of using shear links on all types of frames have been reported. Four types of irregular framed structures have been considered in this study. Two of them comprise geometric irregularity; one is with column discontinuity in the upper story and the remaining frame is with an overhanging mass in the higher story. Shear link braces have been used for individual systems. The shear link includes the bracing in the form of invert " $Y$ ". Finally, a comparison has been made among the irregular frames which contain shear link bracing systems. These frames contain geometric irregularity or column discontinuity. The outcome of the study shows certain effects due to the geometric irregularity/column discontinuity or overhanging mass in a frame that is rehabilitated with shear link steel bracing or invert "Y" bracing. This is because the fact turns into a challenge for a designer to opt for the optimum system for acceptable rehabilitation.

\section{Materials and methods}

\subsection{Materials}

Specifications of materials for numerical analysis have been adopted from the manual of the American Institute of Steel Construction [14]. The details of the member specifications are listed in Table 1. The loading conditions have been considered following the guidelines of UBC97 [12]. Estimation of different parameters for pushover analysis is computed as per the guidelines of FEMA 356 [13]. The relevant properties of the 
frame are demonstrated in Table 1 . The crosssectional properties of the beams and columns of all models are the same. The materials and sections are kept the same for braces and links as well. All types of material sections and property have been adopted as per the American Institute of Steel Construction (AISC).

Tab. 1: Details of members used.

\begin{tabular}{|l|l|}
\hline Members & Configuration \\
\hline Beam size & W16x40 \\
\hline Column size & W21X83 \\
\hline Bracing size & Pipe 5 std. \\
\hline Link Beam size & W6X9 \\
\hline Total story & 6 \\
\hline Bay width & $5 \mathrm{~m}$ \\
\hline Story height & $3 \mathrm{~m}$ \\
\hline
\end{tabular}

\subsection{Description of models}

Frames with irregularity in geometry, discontinuity in columns and overhanging mass along height have been considered for the present study. Bracing with shear links has been added as well to observe the behavior and strength of the dissimilar steel frames with certain irregularities. Four irregular steel frames have been considered for the study. Fig. 1 (Model-1) represents the frame as vertically irregular and asymmetric as well. The 6-story frame having a geometric irregularity in every 2 floors has been taken for pushover analysis. The geometric area, as well as the mass of floor, decreased 25 percent at the $3^{\text {rd }}$ story and 50 percent in the $5^{\text {th }}$ story. Fig. 2 (Model-2) constitutes a frame that has geometric irregularity after the third floor but has symmetry along the vertical axis. Geometric area and floor mass decreased on the $4^{\text {th }}$ floor with a value of 50 percent. Fig. 3 (Model-3) depicts a frame that has column discontinuity at the fourth story. Fig. 4 (Model-4), on the other hand, depicts an overhanging mass on the fourth floor. The bay width and story height of each model are kept constant (refer to Table 1).

\subsection{Pushover analysis}

Pushover analysis is incorporated to assess the nonlinear behavior of the models. The pushover analysis method is mainly adopted in the case of existing structures and to find the nonlinear properties of frames. Several properties: effective stiffness, secant stiffness, and ductility and target displacements along a certain direction can be determined using pushover analysis. The steel frames are assumed as ordinary momentresisting frames and ordinary braced frames. Pushover parameters are estimated from FEMA

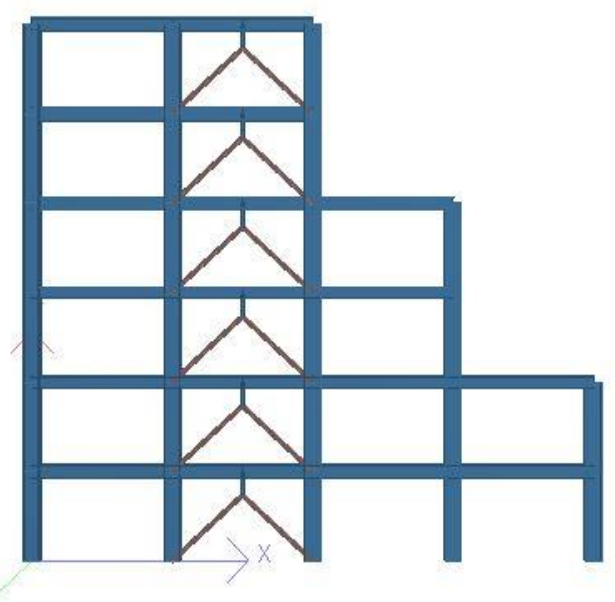

Fig. 1: Model 1.

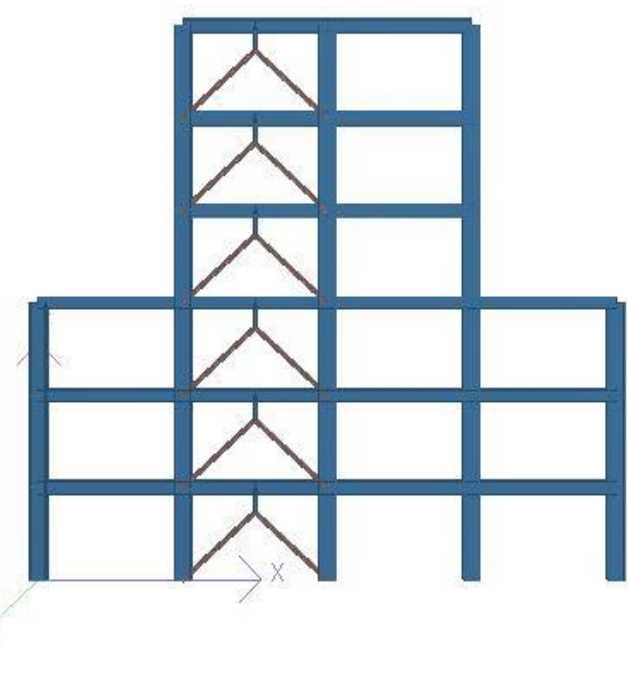

Fig. 2: Model 2. 


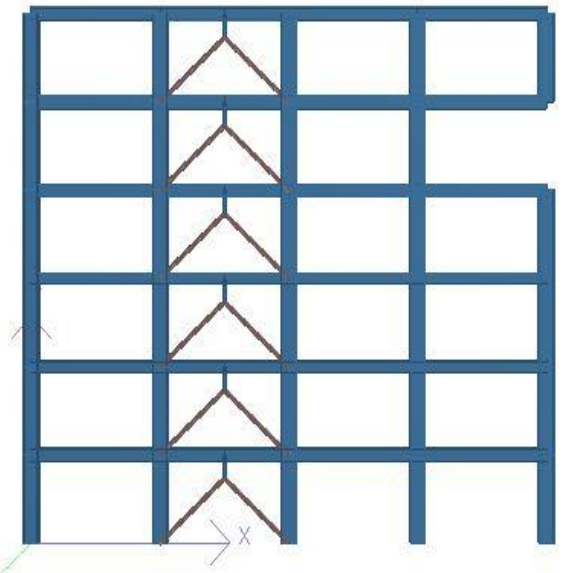

Fig. 3: Model 3.

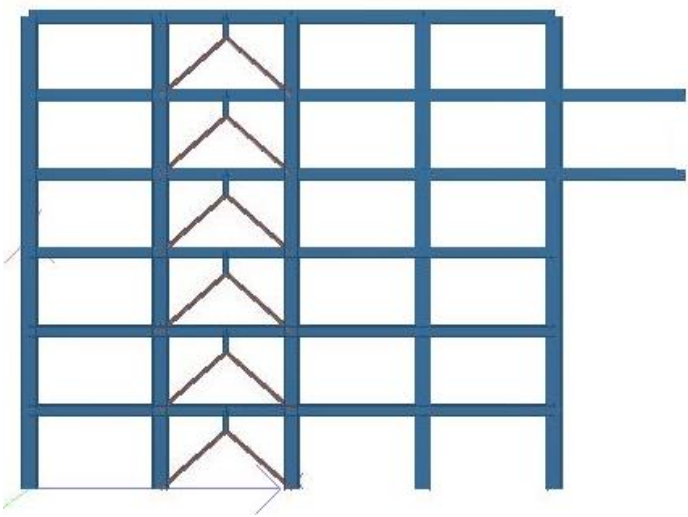

Fig. 4: Model 4.

356 [13]. The behavior of structures can be explained from the force-displacement curve which is recognized as the capacity curve. From Fig. 5 , the behavior of the force-displacement curve can be observed. As per the notations in Fig. 5 , point " $\mathrm{A}$ " represents the origin while point "B" represents the endpoint of the proportional limit. In a linear analysis, the material properties are considered based on the proportional limit. The material property is referred to as the stress-strain or force-displacement curve of a material. The linear portion of the stressstrain behavior is adopted. In pushover analysis, the nonlinear behavior of materials is also considered. The nonlinear behavior as well as the nonlinear hinges starts from point " $\mathrm{B}$ " as

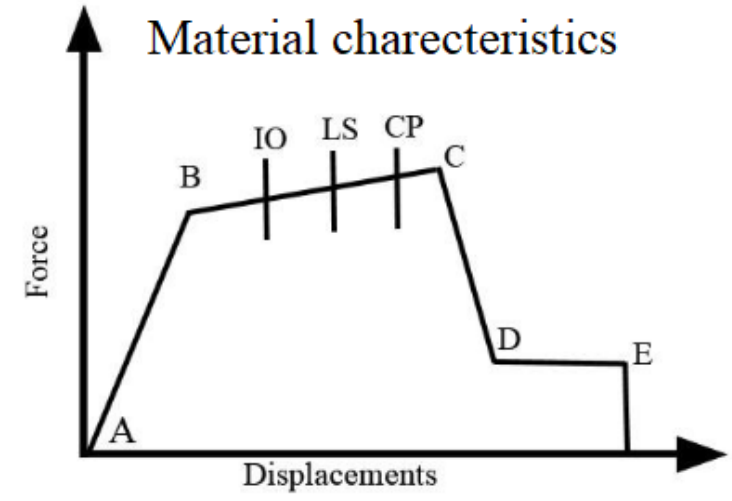

Fig. 5: Force vs. deformation/deformation ratio curve [13].

shown in Figure 5. The nonlinear hinges start from point "B". The hinge levels are computed when the forces reach IO, LS, and CP (Figure 5). After point $\mathrm{D}$, the element responds with substantially reduced strength to point $\mathrm{E}$. The parameters from UBC97 [12] have been listed in Table 2 while the pushover criteria are shown in Table 3.

The Base shears which have been applied for pushover analysis were derived from the following equations. The base shear is distributed over the height of the models and used as a load pattern for pushover analysis.

$$
V=\frac{C_{v} I}{R T} W
$$

where

$$
T=C_{t}\left(h_{n}\right)^{3 / 4}
$$

Tab. 2: Values considered from UBC97 [12].

\begin{tabular}{|l|l|}
\hline Parameters & $\begin{array}{l}\text { Values/ } \\
\text { Standards }\end{array}$ \\
\hline Zone factor, $\mathrm{Z}$ & 0.075 \\
\hline Soil profile type & $\mathrm{S}_{c}$ \\
\hline Seismic importance factor, $\mathrm{i}$ & 1 \\
\hline $\begin{array}{l}\text { Response modification factor, } \\
\mathrm{R}\end{array}$ & 5.6 \\
\hline Seismic coefficient, $\mathrm{C}_{a}$ & 0.09 \\
\hline Seismic coefficient, $\mathrm{C}_{v}$ & 0.13 \\
\hline Near-source factor, $\mathrm{N}_{a}$ & 1 \\
\hline Near-source factor, $\mathrm{N}_{v}$ & 1 \\
\hline $\mathrm{C}_{t}$ & 0.0853 \\
\hline
\end{tabular}


Tab. 3: Pushover parameters.

\begin{tabular}{|l|l|}
\hline Parameter & $\begin{array}{l}\text { Input value/ } \\
\text { system }\end{array}$ \\
\hline Frame type & $\begin{array}{l}\text { Moment resisting } \\
\text { frame }\end{array}$ \\
\hline Geometric Nonlinearity & Included \\
\hline Expected yield stress & $250 \mathrm{MPa}$ \\
\hline Hinge type & As per FEMA356 \\
\hline Damping & $5 \%$ \\
\hline Site category & Class C \\
\hline $\begin{array}{l}\text { Mapped spectral } \\
\text { acceleration, } \mathrm{F}_{a}\end{array}$ & 1.2 \\
\hline $\begin{array}{l}\text { Mapped spectral } \\
\text { acceleration, } \mathrm{F}_{v}\end{array}$ & 1.7 \\
\hline
\end{tabular}

The computed base shear $(\mathrm{V})$ from equation (1) must be less than that calculated by equation (3) and must be greater than that calculated by equation (4). In equation (1), $W$ indicates the self-weight of the frame.

$$
\begin{aligned}
& V=\frac{2.5 C_{a} I}{R} W \\
& V=0.11 C_{a} I W
\end{aligned}
$$

STAAD.pro v8i has been used for pushover analysis. The assumptions through which the pushover analysis has been followed are listed below:

(i) The frames are moment resisting frames.

(ii) The geometric nonlinearity has been considered.

(iii) The expected yield strength has been assumed as $250 \mathrm{MPa}$.

(iv) Total Load step is 100 and the nonlinear hinges have been presumed as per FEMA356.

(v) Deduction of the damping ratio is $5 \%$ and the site class is $\mathrm{Sc}$

(vi) Mapped spectral acceleration factor, $\mathrm{Fa}=$ 1.2 and $\mathrm{Fv}=1.7$

(vii) A certain value has been entered to terminate the pushover analysis after an irrefutable limit.
Linear static analysis following equations (1), (2), (3) and (4) are also incorporated for each consecutive case to obtain the maximum deflection.

\section{Results and discussion}

The analysis of the models is conducted following the provisions of UBC97 [12] and FEMA356 [13] for linear static and pushover analysis sequentially. The equations and provisions are discussed in the previous sections. The analysis demonstrates the behavior of the selected frames. The objective of the research includes the computation of displacement under linear and nonlinear analysis by observing the nonlinear hinge formation in the members. The formation of nonlinear hinges at a certain load-step defines the load capacity of the local element.

Table 4 presents the lateral displacements obtained from linear static analysis while Table 5 and Table 6 define the results of pushover analysis. Table 4 shows the lateral displacements due to the linear static analysis. The differences in maximum displacements of the models are substantial. Model-2 yields less effect while model4 yields the maximum. Normalized differences are obtained by dividing the displacements of the model with the displacement of Model-2. It can be noted that normalized displacements of Model-1 and Model-2 are close. Besides, there is a vast difference in normalized displacements of Models ( $3 \& 4)$ with Model 1 . The computed differences are 25 percent and 29 percent. This indicates the severity of considering overhanging and column discontinuity in any steel-framed structures subjected to earthquake loads.

Tab. 4: Lateral displacements obtained from linear static analysis.

\begin{tabular}{|l|l|l|}
\hline Model & $\begin{array}{l}\text { Maximum } \\
\text { displacement } \\
(\mathbf{m m})\end{array}$ & $\begin{array}{l}\text { Normalized } \\
\text { displacements }\end{array}$ \\
\hline Model-1 & 4.081 & 1.009 \\
\hline Model-2 & 4.046 & 1 \\
\hline Model-3 & 5.045 & 1.25 \\
\hline Model-4 & 5.226 & 1.29 \\
\hline
\end{tabular}


Tab. 5: Nonlinear hinge formation.

\begin{tabular}{|l|l|l|l|l|}
\hline Model Formation of hinge & $\begin{array}{l}\text { Model 1 } \\
\text { Base shear }\end{array}$ & $\begin{array}{l}\text { Model 2 } \\
\text { Base shear }\end{array}$ & $\begin{array}{l}\text { Model 3 } \\
\text { Base shear }\end{array}$ & $\begin{array}{l}\text { Model 4 } \\
\text { Base shear }\end{array}$ \\
\hline Immediate occupancy (IO) & $0.84 \mathrm{~W}$ & $0.89 \mathrm{~W}$ & $0.55 \mathrm{~W}$ & $0.5 \mathrm{~W}$ \\
\hline Life safety (LS) & $1.27 \mathrm{~W}$ & $1.33 \mathrm{~W}$ & $0.91 \mathrm{~W}$ & $0.81 \mathrm{~W}$ \\
\hline Collapse prevention (CP) & $1.44 \mathrm{~W}$ & $1.52 \mathrm{~W}$ & $1.05 \mathrm{~W}$ & $0.90 \mathrm{~W}$ \\
\hline
\end{tabular}

Tab. 6: First formation of the nonlinear hinge in the mainframe (Beam \& Column).

\begin{tabular}{|l|l|l|}
\hline Model & $\begin{array}{l}\text { First Nonlinear } \\
\text { hinge formation }\end{array}$ & $\begin{array}{l}\text { Member } \\
\text { type }\end{array}$ \\
\hline Model-1 & $1.18 \mathrm{~W}$ & Beam \\
\hline Model-2 & $1.24 \mathrm{~W}$ & Beam \\
\hline Model-3 & $0.86 \mathrm{~W}$ & Beam \\
\hline Model-4 & $0.78 \mathrm{~W}$ & Beam \\
\hline
\end{tabular}

In Table 5, the first nonlinear hinge originates for loads with different values. A detailed illustration of hinge development is discussed in Azad et al. [15]. The base shear has been normalized as the fractional ratio of self-weights (W) of each model. The lowest value of base shear to form the first nonlinear hinge is found in Model-4. Model-4 contains an overhanging mass portion the decreases the global stiffness of the structure. Besides, the highest value of base shear to form the first nonlinear hinge is obtained from Model-2. It has symmetry along the vertical axis and it exhibits the stiffest characteristics among the models. Model- 1 and model- 3 have the intermediate value of base shear to originate the first nonlinear hinges. Besides, Models (1\&2) and models (3\&4) have closure shear values to develop hinges.

Table 6 shows that the nonlinear hinges are induced in beams and columns of the mainframe. Note that the minimum load for the formation of hinges in the beam has been found in Model4. The value of the load is highest for Model-2. It can be noticed that the value load for forming hinge in the beam is closure for Models (1\&2) and Models (3\&4).

The formation of nonlinear hinges in beams (Main Frame) for push loads has been represented in Fig. 6. For the consecutive models in Fig 6, it is evident that formations of hinges in beams occur after the generation of hinges in three shear links at different load steps in models 1, 3 and 4, respectively, at the same levels. However, a little bit different has been observed in model-2. Hinge in the beam has been generated after generating hinges in 4 shear links. It can be concluded that Model-2 is the safest model among the considered models.

From Fig. 7, the pushover curve (forcedisplacement curve) of different models can be observed. The value of base shear is plotted along the vertical axis and the value of the corresponding displacements is plotted along the horizontal axis. It is noticeable that the peak value of base shear is highest in Model-2. The lower peak value of base shear can be observed in Model-1. On the contrary, for Model-4, the peak base shear has the lowest value. Model-3 has the intermediate values of peak base shears for corresponding displacements. In this Figure, the peak base shear is considered because the structural strength starts to reduce after this point. It is substantial that the base shear decreases with the increasing displacements that justify that the structural strength is dropping.

\section{Conclusions}

Numerical analysis has been carried out to investigate the effect of vertical irregulars of steel frame with shear linked steel braces. Different types of irregularities have been considered and pushover analysis has been carried out. The study presents results including force deformation curves, nonlinear hinge formation at differential load steps. The differences between lateral displacements due to static load have also been noticed. It is found that the lowest lateral displacements occur in Model-2 while the highest can be found in Model-4. The frame with overhanging mass (Model-4) is the most 

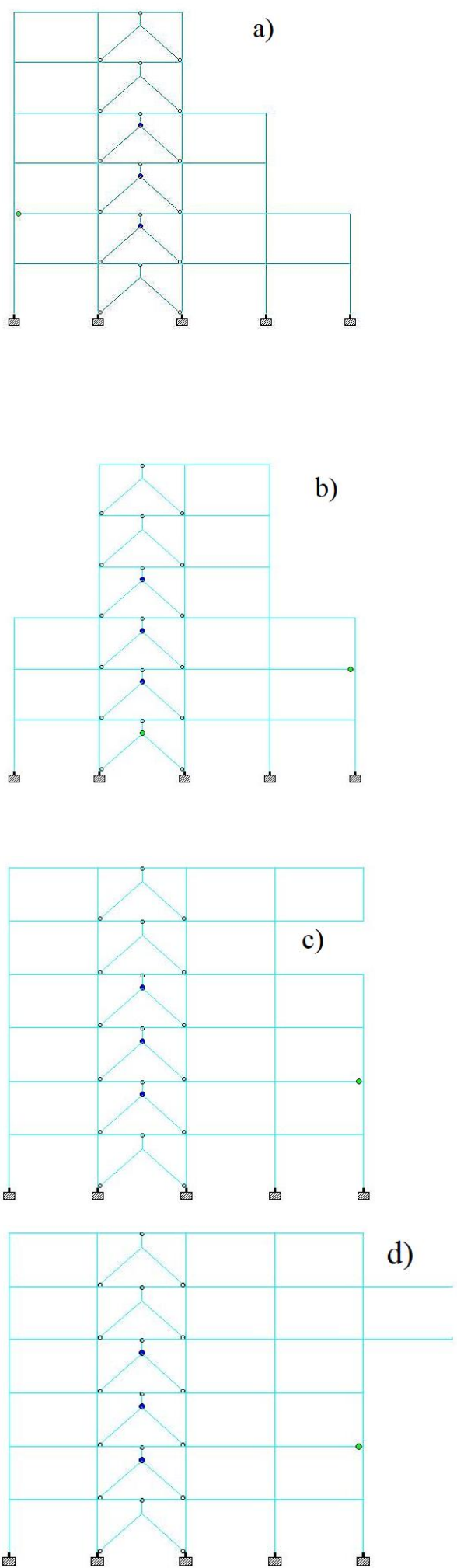

Fig. 6: Nonlinear hinges at beams.

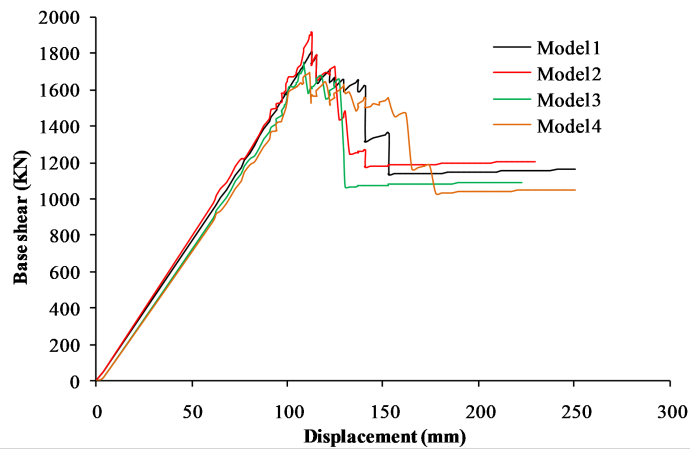

Fig. 7: Capacity curve of all specimens.

critical for the irregularities considered in the present study while model-2 is the safest one, based on the pushover curve, nonlinear hinge formations, and lateral displacements. It is evident that the response from linear static analysis and pushover analysis follows a significant trend. The responses of Models ( $1 \& 2)$ are significantly closed. Moreover, the responses of Models ( 3 $\& 4)$ are also close considering the numerical values. It depicts a model with column discontinuity is also susceptible to vulnerable effects to a good extent. Hence, there is a good agreement between the outcomes of linear static analyses and pushover analyses. As a conclusion, it can be demonstrated that column discontinuity and overhanging mass reduces the frame stiffness to a good extent. The effect of geometric irregularity can be minimized to maintain symmetry while design and planning.

\section{Acknowledgement}

The authors would like to thank Md. Saiful Alam Saif, Lecturer, English Language and Literature, University of Creative Technology Chittagong, for his sincere time to bring grammatical accuracy in this manuscript.

\section{References}

[1] Hosseini, S. H., Bakar, S. A., Bagherinejad, K., \& Hosseinpour, E. (2015). Pushover analysis of reinforced concrete building with 
vertical shear link steel braces: Malaysian Journal of Civil Engineering, 27(2), 169179.

[2] Abou-Elfath, H., \& Ghobarah, A. (2000). The behavior of reinforced concrete frames rehabilitated with concentric steel bracing: Canadian Journal of Civil Engineering, 27(3), 433-444.

[3] Naik, S. B., Saleemuddin, M. Z. M., and Sangle, K. K. (2015). Seismic Performance Evaluation of Reinforced Concrete Frames with Irregular Elevations using Nonlinear Static Pushover Analysis: International Journal of Modern Trends in Engineering and Research (IJMTER), 2 (7), 648-653

[4] Tremblay, R., \& Poncet, L. (2005). Seismic performance of concentrically braced steel frames in multistory buildings with mass irregularity: Journal of Structural Engineering, 131(9), 1363-1375.

[5] Hossain, M. M., Sheen, F. A., Chowdhury, M. S., \& Menon, S. M. R, (2015). Seismic Evaluation of a Simple Steel Structure by Pushover Analysis Procedure. Proceedings of International Conference on Recent Innovation in Civil Engineering for Sustainable Development; DUET - Gazipur, Bangladesh, 528-532.

[6] Chintanapakdee, C., \& Chopra, A. K. (2004). Seismic response of vertically irregular frames: response history and modal pushover analyses: Journal of Structural Engineering, 130(8), 1177-1185.

[7] Das, S., \& Nau, J. M. (2003). Seismic design aspects of vertically irregular reinforced concrete buildings: Earthquake Spectra, 19(3), 455-477.

[8] Islam, M. T., Azad, M. S., Atif, M. F., \& Azad, G. M. S. I. (2018). Effect of position of irregularity in concrete frame on response to seismic forces: BIBECHANA, 15, 121130.

[9] Sazzad, M. M., Azad, G. M. S. I., Azad, M. S., \& Samadder, N. (2018). Effects of Vertical Irregularity in Steel Braced Frames on
Response to Earthquake: Journal of Civil Engineering and Architecture, 12, 106-112.

[10] Azad, M., Sazzad, M., Samadder, N., \& Rahman, M. (2019). Effect of Setback Percentages in Vertically Irregular Concrete Buildings on Response to Earthquake. International Conference on Planning, Architecture and Civil Engineering, Rajshahi, Bangladesh.

[11] Georgoussis, G.., Tsompanos, A., \& Makarios, T. (2015). Approximate seismic analysis of multi-story buildings with mass and stiffness irregularities: Procedia Engineering, 125, 959-966.

[12] UBC97: Uniform Building Code, 1997.

[13] FEMA 356: Pre standard and commentary for the seismic rehabilitation of buildings. Washington (DC): Federal Emergency Management Agency. Building Seismic Safety Council, 2000.

[14] Steel Construction Manual by American Institute of Steel Construction (Fourteenth Edition).

[15] Azad, M. S., Punurai, W., Sinsabvarodom, C., \& Asavadorndeja, P. (2019). Effects of Redundancy in Bracing Systems on the Fragility Curve Development of Steel Jacket Offshore Platform: Engineering Journal, 23 (1), 123-133.

\section{About Authors}

Md Mahmud SAZZAD is a professor in the Department of Civil Engineering at Rajshahi University of Engineering \& Technology (RUET), Bangladesh. He received B.Sc. degree in Civil Engineering from Rajshahi University of Engineering \& Technology in Bangladesh (2000), the M.Eng. degree in Civil Engineering from Saitama University, Japan (2006), and the $\mathrm{PhD}$. degree in Civil Engineering from Saitama University, Japan (2011). He is also the head of the department of Urban and Rural planning. His current research interests include discrete element method (DEM), finite element 
method (FEM), computational mechanics, slope stability analysis, soil mechanics and foundation engineering etc. Prof. Sazzad is the author/coauthor of more than 30 journal articles and 35 conference presentations. $\mathrm{He}$ achieved Gold Medal Award for Outstanding Academic Performance in Bachelor of Science in Civil Engineering at RUET. He was a recipient of the ADB-JSP Scholarshp Program during his master degree and MEXT scholarship during his $\mathrm{PhD}$ degree. He is currently involved as reviewer of: Granular Matter (Springer), Acta Geotechnica Slovenica (Springer), Physica A: Statistical Mechanics and Its Application (Elsevier), Marine Georesources \& Geotechnology, Taylor and francis. He achieved Recognized Reviewer Status Award by Elsevier in September, 2015. He is acting as Editor-in-Chief of International Journal of Advanced Structures and Geotechnical Engineering.

Md Samdani AZAD is a lecturer in the Department of Civil Engineering at University of Creative Technology Chittagong (UCTC), Bangladesh. He received B.Sc. degree in Civil Engineering from Rajshahi University of Engineering \& Technology in Bangladesh (2016), the M.Eng. degree in Civil Engineering from Mahidol University, Thailand (2019). His current research interests include structural dynamics, fatigue of marine structures, seismic assessments of structures, reliability assessments. Azad is the author/coauthor of more 11 journal articles, 3 book chapters and 7 conference presentations. He achieved Mahidol University Postgraduate scholarship-2017 during his master degree. He also received Mahidol University international relation scholarship2017 during this time. He is currently involved as reviewer of: Computational intelligence (Wiley), Journal of Operational Research Society of China (Springer), Jordan Journal of Civil Engineering.

Avishek GHOSH is a lecturer in the Department of Civil Engineering at University of Creative Technology Chittagong (UCTC), Bangladesh. He received B.Sc. degree in Civil Engineering from Ahsanullah University of Science \& Technology in Bangladesh (2015), the M.Tech. degree in Civil Engineering from Indian Institute of Technology Bombay, India (2018). His current research interests include Soil Structure Interaction, Geotechnics, Soil Mechanics, Slope Stability, Geomechanics, Numerical Modeling in Geotechnical Engineering. Mr. Ghosh is the author/coauthor of more than 8 research articles including journal articles and conference presentations. He achieved ICCR Scholarship-2016 during his master degree. He is currently acting as a Coordinator of the Department of Civil Engineering of University of Creative Technology Chittagong (UCTC), Bangladesh. 